\title{
Comparison of Russian (FSB and Old KGB) and Turkish Secret Services (MIT) as an Intelligence Dimension*
}

\author{
Elnur Hasan MIKAIL \\ Kars Kafkas University, Kars, Turkey
}

\begin{abstract}
In this study Russian Federation's current president Vladimir Putin period has been investigated from all aspects. Russian-Turkish relations have a high impact factor from all dimensions for these two countries. Also the secret services of Turkey as Turkish National Intelligence Organization (MIT) and Russia's old Committee for State Security (KGB) and today's Federal Security Service (FSB) are really famous intelligence services as well. KGB was a famous and super power Union of Soviet Socialist Republics (USSR)'s intelligence service until 1991. After 1991 USSR was collapsed and then new Russian secret service by the name of FSB has been created. Today's Russia's president Vladimir Putin was a technological intelligence agent in the Democratic Germany in the USSR period with the colonel degree. In this article we have investigated and researched until the USSR's collapsing date and since that date until today those two countries: Turkey and Russia's secret service's comparison. Also we should take away that the USSR was an empire and Turkey was just a third country as a gendarmerie of USA's in the Middle East as a North Atlantic Treaty Organization (NATO) member. This strategic collaboration has been clarified from all aspects.
\end{abstract}

Keywords: Erdoğan, Intelligence Services, Putin, Russia, The Committee for State Security of USSR (KGB), Turkey, Turkish National Intelligence Organization (MIT), USA

\section{The Rise of Putin}

Vladimir Putin takes his first step to become "the only leader" of the country under circumstances which we tried to outline in upper lines. When Boris Yeltsin appointed this old KGB member whose name had never been heard in national policy in 16th August, 1999, his politic life is thought to be finished in a couple of months later like many other "President of Yeltsin" before him too. According to the comments which took place nowadays in Russian media, Putin's most vital personality was his loyalty and Yeltsin chose him completely because of that reason (Yeltsin, 2000).

His aim was to make his personal defraudation and his dirty jobs not to be irritated after his expiring government. In the following days, it was understood that the mentality represented by Putin was much more

\footnotetext{
* This article has been partially manufactured from the book of Assoc. Prof. Dr. Selim BAŞAR, Assist. Prof. Dr. Elnur Hasan MİKAİL; Turkish-Russian Political and Economic Relations During Erdoğan-Putin Period Between 2003-2013 Years, Sage Publishers, Ankara/Turkey, January/2013, 188 pages (ISBN: 978-60-4738-33-5).

Elnur Hasan MIKAIL, Ph.D., Assistant Professor, Head of Department of International Relations, Faculty of Economics and Administrative Sciences, Kars Kafkas University.

Correspondence concerning this article should be addressed to Elnur Hasan MIKAIL, Head of The Department of International Relations, Faculty of Economics and Administrative Sciences, Kars Kafkas University, Central Campus 36100, Kars/Turkey. E-mail: emikail@turansam.org.
} 
than that (Lepper, 1976).

The thing which made Vladimir Putin's star shine was the Chechnya problem which had prepared many organizer politicians' political death. In the same month when Putin became president, Shariatic Vahhabi Operation which got Saudi Arabia's and Pakistani's assistance directly and USA's assistance indirectly made a critical movement and entered their neighbour country Dagestan. The declared aim was uniting Chechnya and Dagestan under Sharia's flag and ran away after the Russians founding the Independent Islamic Government. This group which did not hesitate to show Chechnya people's national demands to the western imperialists for the sake of their benefit was expecting that the corruption seen in all fields in the last period of Yeltsin in Russia would be beneficial for their case and after 1994-1996 war Russian army would hesitate to embark a second Chechnya adventure (Lewis-Beck \& Tom, 1992).

Yet Vahhabi's Dagestan attack meant the "last drop" in Caucasia for Russian imperialism. First of all, the oil pipeline between Baku (Azerbaijan) and Supsa (Georgia) was opened again with the support of USA. After that event, Azerbaijan and Georgia signed an agreement for Baku-Ceyhan pipeline. The usage of these two pipelines which were planned to be secured by North Atlantic Treaty Organization (NATO) meant that even a gram of oil would not drain from the Russian land. If the Vahhabi attack directed towards Dagestan meant the Chechnya's first step of gaining independence from Russia, the same thing could happen in this area too. Russia was under threatened of losing North Caucasia. The bombs which exploded in Moscow and the other big cities respectively and which caused approximately 300 civilians' death helped to Putin's government to manufacture public opinion for a counter attack. The Russian attack which still continues was started in September 1999 (Mansur, 1999).

Russia's first military success conduced to shine Putin's star. With the contribution of "the independent media" which was under Kremlin's control this old spy who was seem insignificant a few months ago was propagated as "the iron fist which Russia needs" (Retrieved from http://www.mid.ru).

Yeltsin, with a last movement, suddenly resigned on December 31 in 1999 and assigned his place to Putin until the election. The three months time after the resignation which caught the outs unawares would be enough to ensure success for Putin in the election (Ul'yanovsk Oblast Committee of State Statistics, 2000).

Especially after the Sochi Summit between Vladimir Putin and Recep Tayyip Erdogan, some interpretations of that sort had been also made in Turkey. Authorities, who had decoded the game of Putin, which consists in using the difficulties that Erdogan had lived through in the United States as a trump and thus having Turkey on Russia's side in the Middle East and the CIS region, also uttered their anxieties about the fact that in Sochi, hours long discussions had been made without taking minutes. The same authorities seem to struggle devotedly in order that the "ex-KGB man" will not deceive the Turkish Prime Minister (Key, 1966).

This funny wolf-lamb fable apart, there are many problems in the Turkish-Russian relations that should be seriously pondered on. To understand what economic gains would bring such reflections to Turkey, it is enough to look upon the mutual trade course of the last years. Turkey has to take more profit from this giant potential that is Russia in the name of its own national interests. All the same, that must not be an alternative and/or a threat to the United States or the European Union. Thus, Turkey, which has strong relations with its neighbours, will be able to act more confidently in its relations with its western interlocutors (Retrieved from http://www.axisglobe.com/article.asp?article=312). 


\section{Toward a New Geopolitics}

Russia has a regional profile and is sensitive about losing its influence in ex-Soviet territories. Since 1991, Turkey has emerged as a significant regional player, pursuing a special relationship with the E.U. and paying serious attention to building good relations in the Caucasus and Central Asia. How closer Turkish-Russian relations will be interpreted in Brussels and Washington is another important question (Zharmukhamed, 2004).

The U.S. military deployment in different parts of Eurasia, the pro-Western change in domestic landscapes of Georgia and Ukraine, the U.S. wars in Afghanistan and Iraq are, among others, the developments that have paved the way for the emergence of a new geopolitics in Eurasia. The European and U.S. expansion into former Soviet territories influences Russian policymakers to seek new alliances in Asia. Russian rapprochement with Iran, China, and India are examples of this new policy. In this sense, the new developments in the aftermath of the 9/11 attacks are bringing together the policies of not only Russia and other major Asian powers, but also of some critical European states such as France and Germany (Sezer, 2001).

After receiving a negotiation date for E.U. membership, Turkey is emerging as a European actor in the region. However, Turkey's new orientation was tested during the subsequent domestic transformations of Georgia and Ukraine. Turkey adopted a low-profile attitude toward the Russian policies vis-à-vis Ukraine and Georgia, and sensitively displayed a constructive outlook by pointing to the relevant international norms and agreements as the way to resolve the crises. Ankara tries to avoid taking sides in any "Russia versus the West" struggles, while developing its own relations with Moscow. ${ }^{1}$

One other important area of contention is Turkish-Armenian relations, which are held hostage to historical enmities and Turkey's pro-Azerbaijan policies in the Caucasus. Currently, Russia is the main ally of Armenia, and possible Russian mediation between Turkey and Armenia on a number of issues can be expected. Following recent positive developments on this front, there may be Russian-Turkish joint attempts to solve the Armenian-Azerbaijani conflict. ${ }^{2}$

\section{The Weakest Link of Turkish-Russian Relations}

The authors attended an important meeting in Moscow at the President Hotel last week which happened in winter of 2006. The 2006 Awards of Merit were handed out at the ceremony sponsored by the Association for Business and Friendship between the Russian Federation and Turkey (RUTID).

The jury picked important figures and institutions that made significant contributions to the reinforcement of Turkish-Russian friendship in the fields of economy, art, sports, and media. Both Zaman and Russia's prominent daily Izvestia were given awards in the media category. Turkish and Russian intellectuals and businessmen gave short speeches on furthering bilateral relations and friendship. The authors had the opportunity to gather together with a number of Russian colleagues. The authors overall impression of contacts there is that two historically hostile countries that fought numerous wars in the past are now maintaining friendly relations for the first time in their histories. This is a unique development. Of course there are many

\footnotetext{
${ }^{1}$ During then Prime Minister Demirel's visit to Moscow, Boris Yeltsin said, "Russia and Turkey will regard each other as friendly states and will go for a full-blooded dialogue and cooperation in all areas", ITAR-TASS, 25 May, 1992.

${ }^{2}$ Report drafted by Dr. Bulent Aras; The Power and Interest News Report (PINR) is an independent organization that utilizes open source intelligence to provide conflict analysis services in the context of international relations. PINR approaches a subject based upon the powers and interests involved, leaving the moral judgments to the reader. This report may not be reproduced, reprinted or broadcast without the written permission of enquiries. PINR reprints do not qualify under Fair-Use Statute Section 107 of the Copyright Act (Retrieved from http://www.pinr.com/report.php?ac=view_printable\&report_id=265\&language_id=1).
} 
factors that contributed to the improvement of bilateral relations. For instance, the collapsed blocs after the end of the Cold War created an appropriate environment for rapprochement. People who opted to remain distant until the collapse because of ideological differences today develop sympathy. In summer times, Antalya, a city in the southwest of Turkey, becomes a Russian town where the Russian tourists find inexpensive and high-quality resorts as well as warmth and attention. Russians shift their interest from Antalya to Erzurum in the winter. More importantly, today there is no longer any reason for the enmity between the two countries, expected to last forever, to continue. ${ }^{3}$

The visible improvement in commercial activities is another solid indication as regards the betterment of bilateral relations between the two countries. A significant portion of the huge buildings in Moscow was constructed by Turkish contractors. Turkish giants such as ENKA, Rönesans, Nurol, Alarko, and Gama maintain a line of quality beyond their European competitors. Strong ties were also established in Russia in sectors like tourism, textile, and retail.

Both parties are pleased with the rapprochement. They have every reason to be pleased given that bilateral relations have caused nothing but constant enmity up until recently. They were people of both countries who had to suffer from the deteriorated relations; they remained concerned about a probable state of warfare all the time. Today the situation is very different. Of course Turkish Prime Minister Tayyip Erdoğan and Russian President Vladimir Putin have done much to improve bilateral relations. The leaders created a miracle. Ten years ago it was impossible to imagine that Turkish and Russian leaders would come together for cooperation. However, today both leaders exert their utmost effort to improve commercial and cultural relations. Furthermore, the strengthened ties do not bother other major world political players, including the US and the EU. There is no doubt that this is a huge diplomatic success. The Turkish public's good feelings for Putin and the Russian Public's sympathy toward Tayyip Erdoğan is just like a dream (FBIS-SOV, 1996).

The positive bilateral relations notwithstanding, Turkish and Russian intellectuals or businessmen ask this question in large gatherings: is there any chance that something would break this historically important and solid friendship? In other words, will this friendship be replaced by the old concerns? The commonly held view is "no". There is no going back in Turkish-Russian relations. Above all remarkable bridges were built between the two countries; authorities from both countries who overcame huge obstacles in the fields of education, economics, and culture made enormous progress by which their people were pleased. For this reason state figures would by no means take any step that could be regarded as a retreat from the current situation since such a move would be disruptive to historical friendship (Logan, 1977).

This is the general view. However everybody sees the weakest link of Turkish-Russian friendship. This link is more visible in Turkey. Groups and individuals who were hostile to the opposite camp during the Cold War era are uneasy with the current situation. They do not openly acknowledge their dissatisfaction; however they try to sabotage the friendship between the two countries. Those who can understand Turkey best are able to see the saddest part: A small and marginal group tries to present itself as a friend of Russia but actually has a hidden agenda to sabotage the Turkish-Russian friendship. They engage in disruptive activities relying on the state apparatus and hiding their former identities as intelligence agents (Tidmarch, Lisa, \& Jill, 1984).

The presence of this seemingly friendly group is the weakest link of Turkish-Russian relations. Hopefully this risk does not exist in Russia. But even if it does, the best thing to do at this stage is to keep the bridges

\footnotetext{
3 "Turkish influence in CIS countries on rise" Nezavisimaya Gazeta, December 27, 1995, in FBIS-Central Eurasia-Daily Report, March 1, 1996.
} 
between the two countries alive and intact. This is the wish commonly expressed by the people of both countries; besides, the interests of Russia and Turkey require the continuation of good relations. The progress made so far is a success story for both countries; a story that should not be sacrificed to the concerns of the Cold War era (Retrieved from http://www.todayszaman.com/tz-web/yazarDetay.do?haberno=113726; http://www.deik.org.tr/councils_eng.asp?councilld=61).

\section{Relations With Russian Federation}

There was a flurry of visits between Russia and Turkey soon after the collapse of the USSR. These included the visit of Foreign Minister Hikmet Çetin to Moscow on 20-22 January, 1992, and a reciprocal visit to Ankara by Russian Foreign Minister Andrei Kozyrev next month in February, 1992. During Prime Minister Süleyman Demirel official visit to Moscow on 25-26 May, 1992, the "Treaty on the Principles of Relations between the Republic of Turkey and the Russian Federation" was signed replacing an earlier but similar treaty bearing the same title. This treaty established the legal basis of the relations between the two countries and also confirmed the willingness to improve their relationship. ${ }^{4}$

Russian President Boris Yeltsin was in Istanbul on 25 June, 1992, for the first summit meeting of the Black Sea Economic Cooperation (BSEC). Foreign Minister Çetin paid another official visit to Moscow on 1 March, 1993, while Prime Minister Tansu Çiller made an official visit on 8-9 September, 1993. During the visit, the Joint Transportation Committee and a Working Group in the fields of telecommunications, industry, and transfer of high technology were established (De Figueiredo Jr., \& Weingast, 2001).

Russian First Deputy Prime Minister Oleg Soskovets paid an official visit to Ankara on 15-20 July, 1994, and signed two Protocols on bilateral economic relations and debt rescheduling related to the Turkish Eximbank loans extended during the Soviet Union period. Tansu Çiller visiting Moscow on 9 May, 1995, for the ceremony to commemorate the 50th anniversary at the end of the World War II, held official talks with Russian Premier Chernomyrdin. As President, Demirel visited Moscow on October 25, 1996, to attend the third summit meeting of BSEC (Misckiewicz, 1997).

Prime Minister Chernomyrdin's visit to Ankara on 15-16 December, 1997, was the first visit of a Russian Premier since the collapse of USSR in 1991. Prime Minister Ecevit was in Moscow on 4-6 November, 1999. A Joint Declaration on Cooperation in the struggle against Terrorism, Agreements on Abolition of Visas for Diplomatic Passports, Cooperation in the Veterinary Field and a Protocol on Cooperation in the field of Information were signed during the visit. The Protocol on Joint Economic Commission provided the framework for bilateral economic cooperation (Remmer, 1991).

During Russian Prime Minister Mikhail Kasyanov's visit on 23-25 October, 2000, when he was accompanied by Ministers of Energy, Public Property and Industry, Science and Technology and other high ranking officials, agreements including the formation of a Joint Committee on Cooperation in Defense Industry, were signed. During Russian Foreign Minister Igor Ivanov's visit to Ankara on 7-8 June, 2001, a Cultural Exchange Program for 2001-2003 was signed. Mr. Ivanov and his counterpart also held consultations on possible areas of cooperation in Eurasia (Zhuravskaya, 2000).

In early 2004, Turkish Foreign Minister Abdullah Gul visited Moscow after a gap of eight years. The two sides discussed accusations by the other side of harbouring hostile and terrorist groups, like Chechen and other

\footnotetext{
${ }^{4}$ OzgurUlke, 4 (Turkish Secret Published Newspaper's name).
} 
groups by Turkey and Kurdish groups by Russia. PKK, a Marxist Kurdish rebel group had support from the USSR and its proxy Syria, but Syria was forced to shut down its operations in 1999. Russia has also taken some steps against the Kurds (Schmitter \& Karl, 1994).

But the Chechen led violent actions in Moscow and elsewhere in Russia and terrorist acts in Istanbul have brought realism to their view on international terrorism. This is a major problem worrying Moscow and Ankara. But any agreement after Gul's visit remained unknown. Many Chechen leaders including Akhmed Zakayev, a representative of the so-called president of Ichkeria and Aslan Maskhadov, lived in Turkey. Russians complain that while the activity of the followers of the pan-Islamic, pan-Turkic Nurcular organization, is banned in Turkey, they carry out a wide variety of intelligence service related tasks in Russia (Downs, 1957).

At a press conference, Gul responded that Moscow had supplied Turkey with "a list of Turkish citizens involved in terrorist activity" and that it would be thoroughly studied. He agreed that some of the fighters killed in Chechnya might be Turkish citizens and declared: "Terrorist acts have occurred in Istanbul, and their perpetrators also hold Turkish passports". As for funds collected for humanitarian purposes in Chechnya they are handled by the Turkish Red Crescent, he added. Gul said that Turkey had demanded that "Russia declare PKK, now called Kong La as a terrorist group". The Russians had promised to study the question, the minister added (Seligson \& Miguel, 1989).

Contacts at military level have also been established after the signing of the "Framework Agreement on Cooperation in the Military Field and Agreement on Cooperation of Training of Military Personnel" in January 2002 during the visit of General Kvashnin, Chief of Staff of the Russian Federation to Ankara. Chief of staff of Turkish General Hüseyin Kivrikoglu returned the visit in June 2002. The first meeting of the Joint Military-Technical Cooperation Commission was held in September 2002 in Ankara and the second meeting in November 2003 in Moscow. Relations have also been established at the level of the parliaments. During the visit of the Speaker of the Turkish Grand National Assembly (TGNA) Mustafa Kalemli to Moscow on 14-18 July, 1996, a "Protocol on Cooperation between the TGNA and The Federal Assembly of the Russian Federation" was signed (Moe, 1990).

\section{Russia’s “Kurdish Card” in Turkish-Russian Rivalry}

When Boris Yeltsin proclaimed the "five principles of Russia's Caucasus policy" at the Kislovodsk meeting with the Transcaucasian heads of state and leaders of the republics of the North Caucasus on June 3, 1996, he pointed out that cooperation and stability in the Caucasus were a must for Russia's normal development. According to his view, cooperation in the region "under a strong joint control" could only be done by way of strengthening "federalism", and therefore Russia "intended to continue to carry out its peacekeeping functions" to maintain this process.

In fact, while Yeltsin was proposing this cooperation concept based on Russian hegemonic leadership, he was representing the majority view in Russia which believes that the best way to unite and inspire Russians today is the unification of Russia's people for the purpose of its revival as a "great power". It is not an unwarranted conclusion to link this phenomenon to the imperial explanations of some politicians and elements of the old communist apparatus. Russia appears determined to take initiatives to maintain its "big brother" role in the region and also to take every precaution to meet any challenge from other regional powers to prevent its 
hegemonic policies. ${ }^{5}$

During the early years of the post-Communist period, while Iran's "pariah" position generally excluded it from filling the vacuum in Caucasian and Central Asian politics left by Russia's "temporary departure", the US and its western allies quickly appealed to their North Atlantic Treaty Organization (NATO) ally Turkey to represent the secular and democratic role model for the newly emerging states. With its cultural and ethnic ties to the region's people, Turkey was prepared psychopolitically for the role, and rushed to fill it.

President Turgut Ozal, who was personally interested in Turkic and Islamic ties, traveled to the area many times and signed numerous agreements. Having strengthened his personal friendship with President Bush by supporting America in the Gulf War, he helped to build up the image of an emerging "Turkic world" stretching from the Adriatic to the Great Wall. Until 1993 Turkey took an escalating role in the Caucasus and Central Asia as the "western choice".

As Russian authorities began recovering from the destabilizing affects of the rapid change, and realized there was little to be gained in Eastern Europe, they turned their attentions to the south as Peter the Great had done centuries before. At that time, the Russian Empire's challenge to the south brought a long front stretching from the Balkans to the Caucasus, a "competition line" along which it met with the Ottoman Empire. During that period before the time of nation states and through 13 major wars, this competition line determined the character of conflict in Turkish-Russian relations. It also created a culture of skepticism regenerated by domestic conservative elements which even today poisons the chances for constructive cooperation. With Moscow's renewed perception of Turkey as a major threat to Russian interests in the Caucasus and Central Asia, the Kremlin began conducting a unilateral and exclusionary policy at practically every point in its relations with Turkey, indicating a defection from their promises of cooperation. Given the history of competition, such a defection was not unexpected.

After mid-1993 Russia's unilateralism in its relations with Turkey would be very evident. Russian authorities charged that the Minsk Group which includes Turkey and the US aims simply to sabotage Russian interests. Aleksei Arbatov, Russia's director of the Center for Geopolitical and Military Forecasts, has described Turkey as a military adversary of the near future. Long before these academic analyses, radical Russian politicians mentioned "wiping out Turkey in the process of re-creating the Russian Empire". It was even said that the 1992 Agreement on Friendship and Cooperation between Russia and Turkey was the result of rumors leaked that Turkey was planning to intervene in Azerbaijan. Russia's unilateralism was a natural output of its Caucasian policy which saw "any attempts to encircle its southern borders" as a direct threat to its security, and led a unilateral, Russian-dominated joint action, and hegemonic stability in the region.

The separatist movement in Chechnya, attempts to exclude Russians from Azerbaijani Caspian oil reserves, and the involvement of the "third" parties, mainly Turkey, Iran, and multinational corporations backed by western powers, presented a threat to Russia's integrative policies towards the Caucasus. Since regional interests were categorized as being of vital interest to national security, the response would include every means available. Turkish attempts to broaden its presence in the Transcaucasus and Central Asia, and Russian apprehension that Turkey might now fill the role of "big brother" meant that Turkey fell into this threat category.

While Russia was desperately trying to crush the separatist movement in Chechnya to secure its interests

\footnotetext{
5 By Ersel Aydinli; Ersel Aydinli is a faculty member in the International Relations Department, Kirikkale University, Turkey, and is currently pursuing a $\mathrm{Ph} . \mathrm{D}$. at McGill University.
} 
in the Caucasus, the impression that Turkey was somehow supporting Chechen guerrillas provided a perfect counterattack platform to pacify Turkey not only in the Chechen issue but in overall Turkish foreign policy towards Caucasian oil issues and Central Asia. This platform was the "Kurdish card".

Long before the current post-Soviet rivalry began, there was concern about Russian/Soviet involvement in the Kurdish issue. An article from a July 1946 issue of Foreign Affairs stated that the Kurdish independence movement was considered the most dangerous of all Middle East troubles because of the support it got from Soviet Russia, and that the Kurds' "grievances, ammunition, and fighting nature could make them players in a Soviet game".

The PKK (Kurdistan Workers' Party) became active in the early 1970s as a Marxist-Leninist organization, and was a natural target for Soviet agitation which Turkey, as a NATO country, attracted. After the 1980 military coup in Turkey, the PKK survived as the only anti-establishment terrorist organization in the country, this time as a rural insurgency movement beginning to concentrate on Kurdish nationalism along with its Marxist ideology. Since then Turkey has spent approximately \$6-7 billion annually in this struggle which has claimed the lives of more than 10,000 Kurdish and Turkish civilians.

Most of the terrorist activity has occurred in southeastern Turkey, through which the projected Baku-Ceyhan pipeline will run. A Kurdish threat against a proposed pipeline was discussed in August 1995 when Ahmad Dere, the Kurdistan National Liberation Front spokesman in the CIS, spoke of the Kurdish leadership's intention to obstruct construction of a pipeline for shipping Caspian oil across Turkey. Thus Russia discovered the "Kurdish Card", which could be used against Turkey's rising influence in CIS countries.

The first sign of playing the Kurdish card came with a conference entitled The History of Kurdistan held in Moscow in February 1994, and organized by the Kurdistan Committee and the Kurdistan Liberation Front, both of which were affiliated with the PKK. After the Turkish press discovered that the Russian Ministry of Nationalities and Regional Policy was the co-organizer of the conference, the Turkish Foreign Ministry sent a protest to the Russian Ambassador, and received a response denying all allegations. It went on to say that they would not allow similar conferences to be held in the future, but warned that Turkey should be very careful not to play similar trump cards, such as a Turkic-Muslim Chechen republic. A report published in Nezavisimaya Gazeta some time before the incident, suggested that Moscow might consider using the PKK to exert pressure on the Turkish leadership as a counterweight to Ankara's alleged support for Chechen leader Dudayev. It was also reported by the Turkish press that the Russian Foreign Ministry had started to work on formulating a clear policy on the Kurdish problem in early 1994.

While Kurdish groups from Turkey were exploiting the growing rift between Turkey and Russia, a convention of Kurdish organizations from the CIS ended on October 31, 1994, in Moscow with a decision to establish a "Kurdish Union", with the PKK as its nucleus. The PKK had chaired the three-day convention. It was noteworthy that Moscow refrained from any action against the gathering despite the fact that the organizers themselves acknowledged the PKK link.

Turkish Foreign Ministry Undersecretary, Ozdem Sandberk, flew to Moscow to discuss the matter, but again the Russians denied the PKK link. During the same period that the representative of Kurdistan's National Liberation Front in the CIS was urging the Russian president to act as a "mediator and peacemaker between the Kurdish movement and Turkey", he was calling the Caspian pipeline project a "manifestation of pan-Turkic plans".

At the end of 1994, Turkey was still treating the Chechnya issue as an internal matter of the Russian 
Federation, but as the Russians began to intensify the attack in Chechnya and to perform indiscriminate air raids resulting in high civilian casualties, Turkey faced the dilemma of whether or not to speak out. Moscow chose this time to host PKK officials in an effort to draw attention to Turkey's sympathy for the Chechens and win more support from influential sources in Russia for the separatist Kurdish movement by opening a Moscow bureau. The Russian official response to the Turkish Ambassador in Moscow was that the PKK bureau in Moscow was opened for "Kurdish cultural activities only".

By early 1995, the PKK-Chechnya circle was becoming more apparent. The Russian Ambassador to Ankara presented Turkish officials with evidence of a flow of weapons to Chechnya via Turkish territory. As the Russians complained about the matter, two former Kurdish members of the Turkish parliament who had fled the country to found the Kurdish parliament in exile came to Moscow to pursue their goals. The Russian Foreign Ministry again denied any affiliation of Russian officials with these attempts, while simultaneously allowing the "Kurdish House", a Kurdish center under PKK control, to open in Moscow.

Public opinion in Russia was becoming more sensitive about the alleged Chechnya-Kurdish connection, and began blaming the west for being softer on Turkish activities in Kurdistan than on the Russian ones in Chechnya due to overlapping Turkish and Western interests on the "project of the century" on "Caspian oil". As Turkey began to recognize the seriousness of the situation and of PKK dominance in "cultural activities" in Moscow, officials were sent to Russia, and a "Protocol to Prevent Terrorism" was signed. Moscow would forbid the PKK in Russia.

This first agreement marked the initiation of a cycle of the PKK or Kurdish-related activities in Russia followed by Turkish protests, and Russian denials of any official responsibility but tacit approval of their continuation. Turkey's extreme sensitivity on the issue meant that subsequent negotiations would eventually end with oral or written agreements for Turkey's not getting involved in the Caucasus in general, and Chechnya in particular. Russia had found Turkey's most vulnerable side.

At the end of January 1995, Russian officials visiting Turkey repeated that Russia would not allow the Kurdish House and the PKK in Russia, in turn Turkey appeared to agree to taking a low profile regarding Russian efforts to reassert its presence in the Caucasus.

Within this atmosphere, Russia started to storm Chechnya, and Turkey made only empty and weak protests. Russia even conducted joint military maneuvers with Armenia near the Turkish border, demonstrating the seriousness of its intentions in the Transcaucasus. On the other side, Turkey was trying to fold up its six-week-old cross-border operation against PKK separatists in Northern Iraq, with little protest from Russia.

Turkey and Russia reiterated on July 21, 1995, that they would not tolerate separatist movements threatening the other's territorial integrity. While Turkish officials were assuring that the Chechen organizations in Turkey would not be allowed to engage in activities, Albert Chernyshev, former Russian Ambassador to Turkey and later Deputy Foreign Minister, having said previously that Russia considered the Kurdish problem to be Ankara's "internal affair", was saying, "we must understand each other. People who live in glass houses should not throw stones". Chernyshev might well have been describing the hub of Turkish-Russian relations with a realistic approach. This speech also marked the fact that Russia's Kurdish card was operating still, and would be one of the strongest leverages of Russian foreign policy strategists to pacify Turkey and to thwart Turkish desires to become a regional power in the Caucasus.

Towards the end of 1995, Russia would play the card further. Members of the Russian Duma agreed to host the third international conference of the Kurdistan Parliament in exile. The Russian executive branch 
blamed the Duma, but Turkey remained unconvinced, and the act was publicly considered as one of "Russian treachery". Russia was also ignoring the Conventional Forces Reduction Agreement in which it had agreed to reduce its forces on NATO's northern and southern flanks. Turkey's already intimidated position could not meet this challenge of Russian unilateralism.

In 1996 Russia applied to the Kurdish card repeatedly, placing Turkey in a defensive position which was often at the expense of the dynamism of its policies towards the Caucasus and Central Asia. The year witnessed a heavy diplomatic traffic to repair the wounded relations between the two countries.

The January 1996 seizure of the Avrasya sea ferry by the pro-Chechen terrorists escalated already tense communications between the parties. Yeltsin showed his dissatisfaction with the handling of the crisis, claiming that Turkey had delayed liberating the hostages in order to keep international attention on the Chechnya issue. In March, the undersecretary of the Turkish Foreign Ministry conducted official talks in Moscow calling for a "new era in ties", and stated that the Russians had prevented the setting up on Russian soil of a radio station operated by the PKK. The Russians, having secured the early Azerbaijani oil flow through the northern route as opposed to the Turkish route, were saying that they were satisfied with Turkey's position on the Chechen crisis. Despite the rhetoric, Russia appeared determined to use the PKK card. At a meeting with the PKK and Aleksandr Nevzorov, a department head of the ministerial-level Internal Intelligence Service, Russian government officials openly declared that the PKK was not a terrorist organization, and that Russia should use the Kurdish issue to pressure Turkey. In July, the Turkish Parliament Speaker was told by the Russian Prime Minister that he did not have specific information about PKK activities, but he would have the matter investigated.

Shortly thereafter, Russian and Turkish journalists discovered a Kurdish camp, administered and sponsored by the PKK. This camp had been used in part as a clinic to treat wounded PKK members and was located within a three hour drive of the Kremlin. The correspondent of the Russian daily Komsomolskaya Pravda ironically mentioned the similarity between this incident and the "Chechen guerrillas lick[ing] their wounds with the help of the Crimean Turks".

Despite Turkey's continued passive position on Chechnya and the Caucasus, Russia had become less conciliatory, deeming it unnecessary even to verbally support Turkey against the PKK. Turkish plans to set up a security zone in northern Iraq to prevent PKK attacks received stern warnings from Moscow.

In October 1996 Turkish President Demirel met with Russian Premier Chernomyrdin following meetings of the Black Sea Cooperation Organization. Chechnya and the PKK were the major topics of discussion at this high level meeting. Once again Chernomyrdin promised the administration would stop any "political" PKK activities in Russia. So far, an intimidated Turkish foreign policy caused by the cycle has helped Russia to gain time for dealing with the Chechnya problem, and to obtain one of the two early oil routes for Caspian oil. When Viktor Ustinov, Chairman of the Committee for Geopolitics of the State Duma of Russia called on the Kurds and Russians for "joint work" to create an independent Kurdish state, it was clear that the separatist PKK organization was playing a sizable role in frustrating practical realization of the pipeline project's "Mediterranean option".

In December 1996, Deputy Prime Minister Ciller paid a visit to Moscow to discuss PKK/Chechen affairs with the hope of normalizing relations. Again the Russians made mention of arms shipments from Turkey to Chechnya, a charge which Turkey denied. In turn Turkey brought up the PKK issue and was met with firm denials. The visit seems destined to become another in the cycle of failed diplomatic rhetoric. 
The skeptical and chaotic character of five centuries of Turkish-Russian relations continues to prevail and to promote defection from any cooperation in the Caucasus and Central Asia. In the current era, the syndrome of fear of being divided inherited from the collapse of the Ottoman Empire, forces Turkey to try and stop the Russians from playing the Kurdish card at any cost. To do so they must stay away from Russia's hegemonic policies in the Turkic world of the Caucasus and Central Asia. There is no doubt that Russia has played the Kurdish card effectively, and the challenge of the PKK has severely restricted Turkey's ability to play a strong role not only in the Caucasus and Central Asia but also in the Balkans, in particular the Bosnian conflict. The Kurdish card has given Russia unprecedented leverage in its relations with Turkey. Unless Turkey is able to find a solution to its PKK problem, it seems likely that Russia will continue to use the Kurdish card to secure its strategic interests (Retrieved July 24, 2007, from http://ourworld.compuserve.com/HOMEPAGES/USAZERB/232.htm).

\section{Conclusions}

By looking at the current developments, it can be concluded that Turkish-Russian relations will improve in the political, economic, and security realms. However, the relations are not free from a number of serious problems that could threaten to derail these growing ties; both countries have converging and conflicting interests in neighboring regions, and this status makes Turkish-Russian relations promising yet difficult. Turkey and Russia are two influential actors in the Eurasian geopolitics and their relations have implications for the whole Eurasian region. Because of this, internal and external players in Eurasian geopolitical gambling will keep an eye on this growing relationship.

This book examines the increasing and intensified cooperation between Russia and Turkey as a central feature of Central Eurasia's post-Cold War restructuring, and seeks to explain their cooperation with reference to major theories of international relations. It argues that the diminution of the Russian threat is what allowed for the possibility of Turkish-Russian cooperation.

Rapidly developing economic cooperation remains a backbone of mutual relations and simultaneously, promotes political rapprochement. With the realization of large joint projects in the sphere of heavy industry, electric power industry, aviation and a railway communication, food and the building industry, the military sphere and tourism, so will a Russian influence on the Turkish economy and foreign policy inevitably increase. Taking into account Turkey's rapidly growing dependence on deliveries of Russian natural gas and projects in the energy sphere, this influence can lead to the changes in the political priorities of Ankara. The concept of this Euroasian cooperation in both countries is based on economics, but it can also find a political expression.

In such a case, if the tendency for economic rapprochement leads to coming together political interests, Turkey will gradually and inevitably leave the American sphere of influence. Economic cooperation with Turkey strengthens Russian political position in the area, particularly, in Caucasus and in Central Asia. This leads to the concealed division of the spheres of influence between Moscow and Ankara aimed to prevent US penetration in the region. The countries in the area will be inevitably involved in joint Russian-Turkish economic projects and consequently, involved into a political orbit of Russian influence.

Turkey's dependence on the Russian energy carrier's deliveries is gradually rising. Despite the US negative attitude towards projects of Russian oil deliveries by pipelines to the Mediterranean Sea (since it will strengthen Russia and will reduce deliveries of oil through the BTC), Ankara is ready to participate in them.

Evidently this supports a viewpoint that Turkey hopes to take into account the interests of its northern 
neighbor at the expense of the traditional union with America. The increasing dependence of Turkey on deliveries of Russian gas, and joint projects with Russia in the field of energy and power will inevitably increase the growth of Ankara's political dependence on Moscow.

At the time when Russia and Turkey are exchanging diplomatic visits at the highest level and when mutual trade and investment continues to grow at unprecedented levels, it is difficult to understand how Turkey's willingness to extradite a notorious but relatively minor Chechen figure could further improve those relations. Aside from the occasional low-level attempt at scandal, such as the recent release of an FSB propaganda film conveniently portraying the Turkish National Intelligence Organization (MIT) as a candidate to replace the CIA as a threat to Russia in the wake of Putin's support for America's war on terrorism, Russia has not given any significant indication of displeasure with Turkey's stance on Chechnya.

Unless Moscow chooses to pose a direct challenge to Turkish security by, for example, reactivating contacts with the PKK, there is no reason to expect Turkey to reverse course and begin assisting the Chechens as it did in the first war. The September 11 attacks only heightened the Turkish security establishment's determination to quash Islamic radicalism, and it will continue to regard with great suspicion all causes associated with that movement, including the Chechen cause. Active support for Chechnya in Turkey will remain restricted to a badly split Diaspora community, a dispirited and embattled Islamist movement, and thoroughly marginal political figures such as Besim Tibuk.

Given the sharply circumscribed nature of the support, the Turkish contribution to the ability of the Chechens to resist can only be negligible. Those who believe that Chechnya can be pacified by cutting outside sources of supply would do well to consult the archived debates of the Cheka, the forerunner to the KGB, regarding its attempts to pacify Chechnya in the 1920s. While some Cheka officers preferred to rage about suspected aid trickling in from "bourgeois Georgia", others more soberly observed that the Cheka's own brutality had given the region's inhabitants no choice but to fight. If Russia hopes to defeat radicalism in Chechnya today, it would do better to curb the atrocities of its own forces than fulminate about foreign sources of aid.

Turkey and Russia are two countries which have several economic relationships come from the history. Aside from the political disputes that arise from time to time between countries, trade and economic relations are constantly developing. Indeed, of Turkey and the Russian Federation are the two major trade partners. Turkey imports a significant amount of goods from the Russian Federation. The Russian Federation is also an important export market in Turkey. In the same way, Russia is exporting a significant amount of goods and services to the Turkey, and Turkey also imports large quantities of goods and services.

The fact that the two countries are geographically close ranks is an advantage in trade relations. It is important to develop trade and economic relations between the two countries. Outside of the traditional textile and natural resources trade, other goods and services trade must be developed. In particular, it should cooperate in the fields of tourism, health, banking, and transportation. In addition, to cooperate in terms of education will contribute to the development of human capital in the future.

Turkey should give importance to the quality of products which exports to the Russian Federation. In fact, Turkey is faced with competition with its European rivals, especially in this area. Russia should diversify their export product to Turkey. 


\section{References}

De Figueiredo Jr., R. J. P., \& Weingast, B. (2001). Russian federalism: A contradiction in terms. Retrieved November 24, 2001, from http://www.hoover.stanford.edu/publications/digest/014.Weingast.html

Downs, A. (1957). An economic theory of democracy. New York: Harper.

FBIS-SOV. (1996). Yeltsin Not Satisfied with the Handling of Eurasia (Avrasya).

Key, V. O. (1966). The responsible electorate: Rationality in presidential voting, 1936-1960. Cambridge: Belknap Press.

Lepper, S. I. (1974). Voting behavior and aggregate policy targets. Public Choice, 18, 67-81.

Lewis-Beck, M., \& Tom, R. (1992). Forecasting elections. Washington, D.C.: CQ Press.

Logan, M. B. G. (1977). Short-term economic changes and individual voting behavior. London: Yale University Publishers.

Mansur, R. (1999). Visual travel guides series (Görsel Gezi Rehberleri Serisi) (pp. 34-123). Ankara: Dost Bookstore Publication.

Misckiewicz, E. (1997). Changing channels: Television and the struggle for power in Russia. New York: Oxford University Press.

Moe, T. (1990). Political institutions: The neglected side of the story. Journal of Law, Economics, and Organization, 6, $213-253$.

Remmer, K. (1991). The political impact of economic crisis in Latin America. American Political Science Review, 85, 777-800.

Schmitter, P., \& Karl, T. (1994). The conceptual travels of transitologists and consolidologists: How far to the east should they attempt to go? Slavic Review, 53(1), 173-185.

Seligson, M., \& Miguel, G. (1989). Ordinary elections in extraordinary times: The political economy of voting in Costa Rica. Chapel Hill: University of North Carolina Press.

Sezer, D. B. (2001). Russia: The challenges of reconciling geopolitical competition with economic partnership. Boulder, C.O.: Lynne Riener.

Tidmarch, C., Lisa, H., \& Jill, S. (1984). Press issue agenda in the 1982 congressional and gubernatorial election campaign. Journal of Politics, 46, 1226-1245.

Ul'yanovsk Oblast Committee of State Statistics. (2000). Economic situation in Ul'yanovsk Oblast in 1999 (Ekonomicheskoe Polozhenie Ul'yanvoskoi Oblasti v 1999 godu). Ul'yanovsk: Ul'yanovsk Oblast Committee of State Statistics.

Yeltsin, B. (2000). Midnight chrocicles (Geceyarısı Günlükleri) (pp. 78-90). İstanbul: Türkiye İş Bankası Culture Publication.

Zharmukhamed, Z. (2004). Post-Soviet integration in the light of Kazakhstani-Russian relations. Asia Insights, 2, 17-18.

Zhuravskaya, Y. (2000). Incentives to provide local public goods: Fiscal federalism Russian style. Journal of Public Economics, 76, 337-368. 